\title{
Effect of Supplementation of Chelated Minerals on Serum Mineral Profile of Buffalo Calves
}

\author{
Deepak Kumar ${ }^{1 *}$, Surinder S. Grewal ${ }^{1}$, Ravi Kumar ${ }^{1}$, Ramkaran $^{3}$ and Sajjan Sihag ${ }^{2}$ \\ ${ }^{1}$ Department of Livestock Production Management, ${ }^{2}$ Department of Animal Nutrition, \\ ${ }^{3}$ Department of Veterinary Physiology and Biochemistry, Collage of Veterinary Sciences, LLR \\ University of Veterinary and Animal Sciences, Hisar-125004, Haryana, India \\ *Corresponding author
}

\section{A B S T R A C T}

Fifteen buffalo calves of average six to ten months old were used to determine the effects of supplementation of chelated minerals on their serum mineral profile. Calves were

Keywords

Calves, Chelated minerals, Serum mineral profile, Blood samples.

Article Info

Accepted:

30 October 2017

Available Online:

10 November 2017 divided into three groups each having five animals in such a way that mean body weight was similar $(\mathrm{P}>0.05)$ among the groups. Each group was assigned to one of the following diets as: control diet with conventional mineral mixture $\left(\mathrm{T}_{1}\right)$, diet with $50 \%$ conventional mineral mixture replace with chelated minerals $\left(\mathrm{T}_{2}\right)$ and diet with $100 \%$ conventional mineral mixture replace with chelated minerals $\left(\mathrm{T}_{3}\right)$. Blood samples were collected aseptically at the beginning of the experiments i.e. day 0 , and thereafter at monthly interval periods, during early morning hours before feeding and watering of the animals by jugular vein-puncture. Approximately ten milliliter ( $\mathrm{ml}$ ) of blood was collected from each animal and transferred immediately into a set of sterile plastic tubes without anti-coagulant for serum mineral analysis respectively. It was observed that the serum calcium, phosphorus, copper, zinc, manganese, iron, cobalt concentrations were significantly higher $(\mathrm{P}<0.05)$ in group $\mathrm{T}_{3}$ as compared to $\mathrm{T}_{1}$. The increased level of $\mathrm{Cu}, \mathrm{Zn}, \mathrm{Mn}, \mathrm{Co}$ and $\mathrm{Fe}$ in the serum of the buffalo calves supplemented with chelated minerals might be due to the higher bioavailability of these elements from chelated as compared to inorganic mineral mixture.

\section{Introduction}

Minerals are essential for growth and reproduction and are involved in a large number of digestive, physiological and biosynthetic processes in the body. Animal obtain minerals through the consumption of natural feeds, fodders and supplementation of inorganic salts as mineral mixture in the ration. Minerals are supplied to the livestock through mineral mixture in the inorganic form. One of the major disadvantages of using such supplements is that the minerals from such sources are not fully absorbed due to antagonism and anti-nutritional factors present in the diet. In addition, higher levels of inorganic salt based mineral mixture resulted in increased excretion, which may cause environmental pollution. Therefore, in order to meet the increasing demand of bioavailable elements and to reduce the contamination of surface water and soil, the concept of chelated mineral/mineral proteinate came up (Spears, 1989). A chelated mineral is a mineral such as copper, zinc, manganese, cobalt or iron (there are others) 
that is bonded to "small proteins", peptides or amino acids. The level of chelated minerals in livestock feeding is typically added at $25-30 \%$ of the total mineral in a feed (Jackson, 1993). There are several studies in different animal species with different sources of different mineral elements, which have revealed notable differences in the bioavailability of organic and inorganic minerals. Studies suggest that binding of $\mathrm{Cu}, \mathrm{Zn}, \mathrm{Fe}$ and $\mathrm{Mn}$ with amino acids and peptides can enhance the bioavailability of these trace minerals, thereby leading to improved milk production, growth, reproduction and general health status in livestock (Pal and Gowda, 2015).

Due to the paucity of the literature on the effect of chelated mineral on the mineral concentration of buffalo calves, the present study has been planned to evaluate the efficacy of chelated mineral mixture on the serum mineral profile of buffalo calves.

\section{Materials and Methods}

The experiment was conducted for the period of four months at Buffalo farm, Department of Livestock Production Management, LUVAS, Hisar to study the effect of supplementation of chelated minerals on the growth performance of buffalo calves. The fifteen buffalo calves were randomly distributed into three treatment groups each having five buffalo calves in such a manner that average body weight and age of each experimental group was statistically similar.

In treatment $T_{1}$ (control) animals were fed with seasonal green fodder, wheat straw and conventional concentrate mixture throughout the experiment period while treatment $T_{2}$ animals were fed similar to $\mathrm{T}_{1}$ but $50 \%$ conventional minerals mixture were replaced by chelated minerals. Likewise in treatment $\mathrm{T}_{3}$ conventional concentrate mixture was supplemented with $100 \%$ chelated minerals per animal per day. The amount of concentrate mixture was given to each group in such a way that the experimental ration remains iso-nitrogenous and iso-caloric. The quantity of different feeds given to each group was adjusted at fortnightly intervals so that the overall DCP requirements of buffalo calves were met according to the change in body weight. Blood samples were collected at the beginning of the experiments and thereafter at monthly interval before feeding and watering of the experimental animals. About ten milliliter (ml) of blood was collected by jugular vein-puncture into a set of sterile plastic tubes without anti-coagulant for serum minerals tests.

Blood collected without anti-coagulant were centrifuged at 2500 to $3000 \mathrm{rpm}$ for 25 minutes and serum was separated and used for estimation of biochemical parameters in serum viz. Serum calcium $(\mathrm{mg} / \mathrm{dl})$ and phosphorus (mg/dl) using kits procured from M/S Transasia Biomedical Limited with fully automated Random Access Clinical Chemistry Analyzer (EM 200 ${ }^{\mathrm{TM}}$ Erba Mannheim - Germany). The serum samples were digested in digestion mixture consisting of nitric acid and perchloric acid for estimation of minerals copper, zinc, and manganese, iron and cobalt using by atomic absorption spectrometer- model Pinaacle 900T, S/N PTAS13050201 of PerkinElmer Company.

\section{Statistical analysis}

The data were analyzed statistically using standard methods (Snedecor and Cochran, 1994). The data were expressed as Mean \pm SE and were analyzed by one-way ANOVA using general linear model of SPSS version 16 and Duncan's multiple range tests was applied to test the significance. Significance was declared when $\mathrm{P}$ value is less than 0.05 (Duncan, 1955). 


\section{Chemical composition of the concentrate mixtures (AOAC, 2005)}

Chemical composition of the concentrate mixtures of various proximate nutrients and mineral contents has been presented in table $1,2,3$ and 4.

\section{Results and Discussion}

The present study revealed that serum concentrations of $\mathrm{Ca}$ and $\mathrm{P}$ in treatment group $\mathrm{T}_{3}$ fed $100 \%$ chelated mineral were significantly $(\mathrm{P}<0.05)$ higher as compared to control group $T_{1}$ fed inorganic mineral mixture. The results of the study indicated that supplementation of chelated minerals in place of inorganic mineral mixture improved the serum calcium and phosphorus concentration in growing calves.

It was further revealed that there was no significant effect $(\mathrm{P}>0.05)$ of supplemental trace minerals on serum concentration of $\mathrm{Cu}$, $\mathrm{Fe}, \mathrm{Mn}$ and Co up to 60 days and zinc up to 30 days. However, day 61 onwards the calves in $\mathrm{T}_{3}$ group fed $100 \%$ chelated mineral exhibited high $(\mathrm{P}<0.05)$ serum concentrations of $\mathrm{Cu}, \mathrm{Mn}, \mathrm{Fe}$ and $\mathrm{Co}$ as compared to control group $\mathrm{T}_{1}$ fed inorganic mineral mixture and 31 day onwards zinc concentration in serum became significant $(\mathrm{p}<0.05)$ higher in treatment group $\left(\mathrm{T}_{3}\right)$ than $\mathrm{T}_{1}$ group. Present study revealed serum minerals concentration of calves increased linearly with the increase of days due to mineral supplementation and the effect was more pronounced in group supplemented with chelated minerals that was in treatment group $T_{3}$. Similar observation was recorded by Olson et al., (1999) who reported that supplementation of trace minerals containing $\mathrm{Cu}, \mathrm{Mn}$ and $\mathrm{Zn}$ in organic and inorganic form raised the serum level of respective minerals compared to the control but within sources only Serum $\mathrm{Zn}$ level was found more from organic form than inorganic.

Bhanderi et al., (2008) also reported high $(\mathrm{P}<0.05)$ serum concentrations of $\mathrm{Cu}, \mathrm{Zn}$ and $\mathrm{Mn}$, in male calves fed MBOTMs as compared to control group fed inorganic minerals. Mondal et al., (2008) also found serum mineral concentration of zinc, copper, manganese and iron increased linearly $(\mathrm{P}<0.05)$ with the increase of days due to mineral supplementation particularly in organic mineral $\left(\mathrm{T}_{3}\right.$ and $\left.\mathrm{T}_{4}\right)$ supplemented group.

Serum mineral profile of experimental buffalo calves at monthly intervals has been presented in tables 5-11.

Values are means \pm standard errors; the values in a row with different superscripts differ significantly between the treatments $(\mathrm{P}<0.05)$

Table.1 Ingredient composition of experimental concentrate mixture $(\mathrm{kg})$

\begin{tabular}{lccc}
\hline Ingredient & $\mathbf{T}_{\mathbf{1}}$ & $\mathbf{T}_{\mathbf{2}}$ & $\mathbf{T}_{\mathbf{3}}$ \\
\hline Maize & 15 & 15 & 15 \\
Wheat & 15 & 15 & 15 \\
GNC & 25 & 25 & 25 \\
Mustard Cake & 15 & 15 & 15 \\
Wheat Bran & 27 & 27 & 27 \\
Common salt & 1 & 1 & 1 \\
Mineral mixture & 2 & $2 *$ & $2 * *$ \\
Total & 100 & 100 & 100 \\
*supplemented @ conventional mineral mixture replaced with 50\% chelated minerals & \\
*supplemented @ conventional mineral mixture replaced with $100 \%$ chelated minerals &
\end{tabular}


Table.2 Proximate composition (per cent) of concentrate mixture

\begin{tabular}{cccccccccc}
\hline Treatments & \multicolumn{10}{c}{ Attribute } \\
\cline { 2 - 10 } & DM & $\mathbf{O M}$ & $\mathbf{C P}$ & $\mathbf{C F}$ & $\mathbf{E E}$ & $\mathbf{N F E}$ & $\mathbf{T A}$ & $\mathbf{N D F}$ & $\mathbf{A D F}$ \\
$\mathbf{T}_{\mathbf{1}}$ & 89.77 & 89.3 & 19.93 & 6.97 & 4.12 & 52.36 & 10.70 & 37.44 & 18.60 \\
$\mathbf{T}_{\mathbf{2}}$ & 90.01 & 89.31 & 19.90 & 6.92 & 4.05 & 52.12 & 10.69 & 37.40 & 18.25 \\
$\mathbf{T}_{\mathbf{3}}$ & 89.04 & 89.35 & 19.80 & 6.88 & 4.09 & 52.26 & 10.65 & 37.47 & 18.44 \\
\hline
\end{tabular}

Table.3 Inorganic and chelated elements composition of different mineral supplement in ration of buffalo calves

\begin{tabular}{lcc}
\hline Minerals (\%) & Inorganic Minerals & Chelated Minerals \\
\hline Zinc & $0.9 \%$ & $0.9 \%$ \\
Copper & $0.4 \%$ & $0.4 \%$ \\
Manganese & $0.35 \%$ & $0.30 \%$ \\
Cobalt & $0.15 \%$ & $0.15 \%$ \\
Iron & $3 \%$ & $2.8 \%$ \\
\hline
\end{tabular}

Table.4 Chemical composition (\%) of whole diet fed to the experimental animals

\begin{tabular}{llllllllll}
\hline Ingredients & DM & OM & CP & CF & EE & ASH & NDF & ADF & NFE \\
Maize & 92.20 & 97.50 & 9.03 & 2.65 & 3.39 & 2.50 & 67.70 & 44.36 & 82.43 \\
Wheat & 91.61 & 97.77 & 10.89 & 2.77 & 3.15 & 2.23 & 23.07 & 10.12 & 80.96 \\
Wheat Bran & 92.86 & 93.88 & 12.00 & 11.83 & 1.01 & 27.07 & 49.23 & 16.13 & 48.09 \\
GNC & 92.70 & 90.00 & 39.16 & 8.00 & 8.30 & 7.50 & 19.20 & 10.12 & 37.04 \\
Mustard cake & 93.46 & 93.17 & 34.62 & 8.33 & 6.25 & 6.83 & 23.50 & 13.27 & 43.97 \\
Maize Green & 25.00 & 14.30 & 7.45 & 27.00 & 3.40 & 10.70 & 64.87 & 37.84 & 51.45 \\
Wheat Straw & 90.00 & 78.00 & 2.81 & 35.00 & 1.05 & 12.00 & 74.83 & 51.90 & 49.14 \\
\hline
\end{tabular}

Table.5 Serum calcium concentration $(\mathrm{mg} / \mathrm{dl})$

\begin{tabular}{|c|c|c|c|}
\hline Days & $\mathrm{T}_{1}$ & $\mathrm{~T}_{2}$ & $\mathrm{~T}_{3}$ \\
\hline 0 & $8.64 \pm 0.27$ & $8.80 \pm 0.25$ & $8.66 \pm 0.10$ \\
\hline 30 & $8.82^{\mathrm{a}} \pm 0.24$ & $9.08^{\mathrm{ab}} \pm 0.16$ & $9.40^{\mathrm{b}} \pm 0.18$ \\
\hline 60 & $9.00^{\mathrm{a}} \pm 0.22$ & $9.12^{\mathrm{a}} \pm 0.82$ & $9.40^{\mathrm{b}} \pm 0.18$ \\
\hline 90 & $9.44^{\mathrm{a}} \pm 0.24$ & $9.84^{\mathrm{a}} \pm 0.18$ & $10.7^{\mathrm{b}} \pm 0.30$ \\
\hline 120 & $9.70^{\mathrm{a}} \pm 0.13$ & $10.94^{\mathrm{b}} \pm 0.37$ & $11.94^{\mathrm{b}} \pm 0.15$ \\
\hline
\end{tabular}

Table.6 Serum phosphorus concentration (mg/dl)

\begin{tabular}{|c|c|c|c|}
\hline Days & $\mathrm{T}_{1}$ & $\mathrm{~T}_{2}$ & $\mathrm{~T}_{3}$ \\
\hline 0 & $3.76 \pm 0.08$ & $3.90 \pm 0.11$ & $3.86 \pm 0.15$ \\
\hline 30 & $4.00^{\mathrm{a}} \pm 0.15$ & $4.50^{\mathrm{b}} \pm 0.15$ & $4.66^{\mathrm{b}} \pm 0.10$ \\
\hline 60 & $4.06^{\mathrm{a}} \pm 0.17$ & $4.68^{\mathrm{b}} \pm 0.08$ & $4.94^{\mathrm{b}} \pm 0.12$ \\
\hline 90 & $4.50^{\mathrm{a}} \pm 0.13$ & $4.88^{\mathrm{a}} \pm 0.48$ & $5.70^{\mathrm{b}} \pm 0.20$ \\
\hline 120 & $4.86^{\mathrm{a}} \pm 0.13$ & $5.10^{\mathrm{a}} \pm 0.08$ & $6.04^{\mathrm{b}} \pm 0.18$ \\
\hline
\end{tabular}


Table.7 Serum copper concentration (mg/l)

\begin{tabular}{|c|c|c|c|}
\hline Days & $\mathrm{T}_{1}$ & $\mathrm{~T}_{2}$ & $\mathrm{~T}_{3}$ \\
\hline 0 & $0.45 \pm 0.05$ & $0.48 \pm 0.02$ & $0.50 \pm 0.05$ \\
\hline 30 & $0.56 \pm 0.02$ & $0.57 \pm 0.18$ & $0.60 \pm 0.01$ \\
\hline 60 & $0.61^{\mathrm{a}} \pm 0.02$ & $0.69^{\mathrm{ab}} \pm 0.49$ & $0.79^{\mathrm{b}} \pm 0.05$ \\
\hline 90 & $0.74^{\mathrm{a}} \pm 0.02$ & $0.85^{\mathrm{ab}} \pm 0.06$ & $0.93^{\mathrm{b}} \pm 0.05$ \\
\hline 120 & $0.87^{\mathrm{a}} \pm 0.03$ & $0.96^{\mathrm{a}} \pm 0.02$ & $1.01^{\mathrm{b}} \pm 0.05$ \\
\hline
\end{tabular}

Table.8 Serum zinc concentration (mg/l)

\begin{tabular}{|c|c|c|c|}
\hline Days & $\mathrm{T}_{1}$ & $\mathrm{~T}_{2}$ & $\mathrm{~T}_{3}$ \\
\hline 0 & $0.38 \pm 0.05$ & $0.40 \pm 0.04$ & $0.40 \pm 0.01$ \\
\hline 30 & $0.47^{\mathrm{a}} \pm 0.01$ & $0.52^{\mathrm{ab}} \pm 0.01$ & $0.55^{\mathrm{b}} \pm 0.01$ \\
\hline 60 & $0.64^{\mathrm{a}} \pm 0.01$ & $0.65^{\mathrm{ab}} \pm 0.01$ & $0.68^{\mathrm{b}} \pm 0.13$ \\
\hline 90 & $0.73^{\mathrm{a}} \pm 0.02$ & $0.77^{\mathrm{a}} \pm 0.08$ & $0.81^{\mathrm{b}} \pm 0.09$ \\
\hline 120 & $0.84^{\mathrm{a}} \pm 0.01$ & $0.87^{\mathrm{ab}} \pm 0.01$ & $0.90^{\mathrm{b}} \pm 0.08$ \\
\hline
\end{tabular}

Table.9 Serum manganese concentration (mg/l)

\begin{tabular}{|c|c|c|c|}
\hline Days & $\mathrm{T}_{1}$ & $\mathrm{~T}_{2}$ & $\mathrm{~T}_{3}$ \\
\hline 0 & $0.05 \pm 0.00$ & $0.06 \pm 0.20$ & $0.06 \pm 0.01$ \\
\hline 30 & $0.07 \pm 0.01$ & $0.07 \pm 0.02$ & $0.08 \pm 0.02$ \\
\hline 60 & $0.08^{\mathrm{a}} \pm 0.01$ & $0.09^{\mathrm{ab}} \pm 0.02$ & $0.10^{\mathrm{b}} \pm 0.05$ \\
\hline 90 & $0.12^{\mathrm{a}} \pm 0.05$ & $0.14^{\mathrm{ab}} \pm 0.06$ & $0.15^{\mathrm{b}} \pm 0.05$ \\
\hline 120 & $0.14^{\mathrm{a}} \pm 0.01$ & $0.15^{\mathrm{ab}} \pm 0.08$ & $0.17^{\mathrm{b}} \pm 0.04$ \\
\hline
\end{tabular}

Table.10 Serum iron concentration $(\mathrm{mg} / \mathrm{l})$

\begin{tabular}{|c|c|c|c|}
\hline Days & $\mathbf{T}_{\mathbf{1}}$ & $\mathbf{T}_{\mathbf{2}}$ & $\mathbf{T}_{\mathbf{3}}$ \\
\hline 0 & $0.91 \pm 0.02$ & $0.93 \pm 0.10$ & $0.92 \pm 0.01$ \\
\hline 30 & $0.96 \pm 0.06$ & $1.00 \pm 0.02$ & $1.03 \pm 0.04$ \\
\hline 60 & $1.10^{\mathrm{a}} \pm 0.03$ & $1.18^{\mathrm{ab}} \pm 0.09$ & $1.24^{\mathrm{b}} \pm 0.04$ \\
\hline 90 & $1.38^{\mathrm{a}} \pm 0.03$ & $1.46^{\mathrm{ab}} \pm 0.04$ & $1.56^{\mathrm{b}} \pm 0.06$ \\
\hline 120 & $1.52^{\mathrm{a}} \pm 0.03$ & $1.64^{\mathrm{ab}} \pm 0.05$ & $1.76^{\mathrm{b}} \pm 0.02$ \\
\hline
\end{tabular}

Table.11 Serum cobalt concentration (mg/l)

\begin{tabular}{|c|c|c|c|}
\hline Days & $\mathrm{T}_{1}$ & $\mathrm{~T}_{2}$ & $\mathrm{~T}_{3}$ \\
\hline 0 & $0.20 \pm 0.05$ & $0.22 \pm 0.04$ & $0.22 \pm 0.03$ \\
\hline 30 & $0.24 \pm 0.01$ & $0.28 \pm 0.02$ & $0.29 \pm 0.02$ \\
\hline 60 & $0.30^{\mathrm{a}} \pm 0.04$ & $0.32^{2 \mathrm{~b}} \pm 0.02$ & $0.40^{\mathrm{b}} \pm 0.03$ \\
\hline 90 & $0.35^{\mathrm{a}} \pm 0.07$ & $0.42^{\mathrm{a}} \pm 0.02$ & $0.48^{\mathrm{b}} \pm 0.03$ \\
\hline 120 & $0.43^{\mathrm{a}} \pm 0.02$ & $0.57^{\mathrm{b}} \pm 0.01$ & $0.65^{\mathrm{b}} \pm 0.04$ \\
\hline
\end{tabular}


In another study, Engle et al., (2000) who reported higher $(\mathrm{P}<0.05)$ serum $\mathrm{Cu}$ concentration on 84 days due to $\mathrm{CuSO}_{4}$ and $\mathrm{Cu}$-lysine supplementation. Spears (1989) also found enhanced serum $\mathrm{Cu}$ level from both sources of $\mathrm{CuSO}_{4}$ and $\mathrm{Cu}$-lysine like the present findings. However in contrary to the present findings Tambe et al., (1998) did not find any improved trace mineral profile on chelated and non-chelated mineral supplementation in calves. Higher serum concentration of trace mineral with organic mineral supplementation probably due to higher absorption and retention in tissue level (Boland 2003).

The results of the study indicated that supplementation of chelated minerals in place of inorganic mineral mixture improved the serum mineral profile in growing calves.

\section{References}

A.O.A.C. (2005). Official Methods of Analysis $\left(18^{\text {th }}\right.$ Edn.). Association of Official Analytical Chemists, Washington, DC.

Bhanderi, B.M., Pande, A.M. and S Parnerkar. (2010). Influence of organic and inorganic forms of trace minerals supplementation at different doses on daily weight gain and serum mineral levels in male calves. Livestock Research for Rural Development. 22: 8 .

Boland, P. M. (2003). Trace minerals in Production and reproduction In Dairy cows. Advances in Dairy Technology. 15: 323324.

Duncan, D. B. (1955). Multiple range and multiple F tests. Biometrics. 11(1): 1-42.

Engle, T. E. and Spears, J. W. (2000). Dietary copper effects on lipid metabolism, performance and ruminal fermentation in finishing steers. Journal of Animal Science. 78: 2452- 2458
Jackson, S.G., (1993). Mineral Proteinates Applications in Equine Nutrition. Proceedings of the 9th Annual Symposium: Alltech Biotechnology in the Feed Industry. Lexington.

Mondal, S., Paul, S.K., Bairagi, B., Pakhira, M.C. and Biswas, P. (2008). Comparative studies of reducing level of organic with inorganic trace minerals supplementation on the performance, nutrient digestibility and mineral balance in cross-bred male calves. Livestock Research for Rural Development. 20:7.

Olson, P. A., Brink, D. R., Hickok, D. T., Carlson, M. P., Schneider, N. R., Dentscher, G. H., Adams, D. C., Colburn, D. J. and Johnson, A. B. (1999). Effect of supplementation of organic and inorganic combination of copper, cobalt, manganese and zinc about nutrient requirement levels on postpartum two year old cows. Journal of Animal Science. 77: 522-532.

Pal, D.T., Gowda, N.K.S. (2015). Organic trace minerals for improving livestock production. Feedipedia, Ani. Feed Resources Inf. Sytm.

Snedecor, G.W. and Cochran, W.G. (1994). Statistical methods, Lowa State University press, Ames. Iowa, USA.

Spears, J.W. (1989). Zinc methionine for ruminants: Relative bioavailability of zinc in lambs and effects on growth and performance of growing heifers. J. Anim. Sci., 67: 835.

Tambe, A. S., Deopurkar, V. L., Gulavane, S. U., Puntambekar, P. M. and Patil, M. B.(1998). Effect of chelated and nonchelated mineral supplementation in enhancing post-partum fertility in cows. International Journal of Agriculture Research. 19(2): 129-131.

\section{How to cite this article:}

Deepak Kumar, Surinder S. Grewal, Ravi Kumar, Ramkaran and Sajjan Sihag. 2017. Effect of Supplementation of Chelated Minerals on Serum Mineral Profile of Buffalo Calves. Int.J.Curr.Microbiol.App.Sci. 6(11): 4242-4247. doi: https://doi.org/10.20546/ijcmas.2017.611.498 